\title{
Recycling of cellulose from vegetable fiber waste for sustainable industrial applications
}

Reciclarea celulozei din deșeuri de fibre vegetale pentru aplicații industriale sustenabile

\begin{abstract}
Recent, două subiecte au devenit importante pentru industria textilă, și anume "asigurarea sustenabilității prin reutilizarea deșeurilor textile" și "dezvoltarea unor materii prime textile noi cu valoare ridicată". Celuloza, care este un polimer fascinant, a fost utilizată de ani de zile ca materie primă pentru a obține diverse produse, cum ar fi: hârtia, fibrele și peliculele. În acest studiu, se urmărește asigurarea durabilității prin reciclare a celulozei din deșeurile de fibră de iută, ținându-se cont de cantitatea de deșeuri de fire de bătătură din iută eliberată în procesul de producție a covoarelor. În acest scop, la început, s-a efectuat curățarea preliminară a deșeurilor de fibră, apoi s-a realizat extracția celulozei și, în final, s-a efectuat caracterizarea celulozei reciclate. Metoda de extracție cu acid organic a fost eficientă pentru izolarea celulozei din deșeurile de fibre, cu un randament de 43,65\%. Analizele microscopic și experimentale au confirmat faptul că partea ne-celulozică a deșeurilor de fibre a fost îndepărtată cu succes, iar celuloza reciclată are o structură similară cu proba martor de celuloză. Rezultatele sugerează că reziduurile de fibre vegetale pot fi utilizate ca sursă potențială de celuloză. Celuloza reciclată poate fi utilizată în producția de hârtie, compozite, fibre de celuloză regenerată și alte aplicații industriale.
\end{abstract}

Cuvinte-cheie: deșeuri de fibre, reciclabil, celuloză, extracție, sustenabilitate

\section{Recycling of cellulose from vegetable fiber waste for sustainable industrial applications}

Recently two significant topics that became important for textile industry namely 'providing sustainability by reusing of textile wastes' and 'developing high-valued new textile raw materials. Cellulose, which is a fascinating polymer, has been used for years as a raw material to obtain various products such as papers, fibers and films. In this study, it is aimed to provide sustainability with recycling of cellulose from waste jute fibers, considering the amount of waste jute weft yarns released in the production process of machine carpets. For this purpose, pre-cleaning of waste fibers was carried out at first, and then extraction of cellulose was accomplished, and finally characterization of recycled cellulose was performed. Organic acid extraction method was effective for isolation of cellulose from waste fibers with $43.65 \%$ yield performance. Microscopic and experimental analyses confirmed that non-cellulosic part of waste fibers were removed successfully and recycled cellulose has similar structure with control cellulose. Our results suggest that, waste vegetable fibers can be used as a potential source for cellulose. Recycled cellulose can be used in the production of paper, composites, regenerated cellulose fibers and other industrial applications.

Keywords: waste fibers, recycle, cellulose, extraction, sustainability

\section{INTRODUCTION}

Natural fibers have been used as textile raw materials since antiquity. Today each year approximately 35 million tons of natural fibers are harvested by farmers from a wide range of plants and animals [1]. These renewable and sustainable fibers are still raw materials of apparel, home textiles and technical textiles. Among the natural fibers, vegetable fibers such as cotton, jute, hemp and flax have high annual production. Vegetable fiber wastes in the forms of fiber, yarn and fabric release during production processes and after usage of textiles. These vegetable fiber wastes include valuable polymers such as cellulose and lignin which can be recycled and used as a raw material of composites, papers and anew textiles. Therefore, in the recent years, researches have focused on recycling and sustainability in the textile sector in conjunction with the other branches of industry [2]. Limited resources and increasing consumption make the recycling and waste management a necessity instead of a choice.

Cellulose, which is a fascinating polymer, has been used for years as a raw material to obtain various products such as papers, fibers and films. Plants are the major source of cellulose and numerous studies have been carried out to extract cellulose and/or nano-cellulose from several plants and itsderivate by using different methods [3-4]. For instance, the physicochemical characterization of the cellulose extracted from the forestry residue of ficus leaves using chemical method was carried out by Reddy et al. In the study, detailed chemical composition of the ficus leaf fibers and extracted cellulose was discussed [5]. Besides, numbers of studies also increase on recycling cellulose from waste materials [6-7]. Kopania et al. present the results of cellulose fiber extraction from waste plant biomass including: rape, hemp and flax straws [8]. Vegetable fibers contain high amount of cellulose, which can be extracted and 
reused as a raw material in various industry. Moran et al. studied on extraction of cellulose and preparation of nano-cellulose from sisal fibers. Feasibility of extracting cellulose from sisal fiber, by means of two different procedures was carried out and compared [9]. Acid hydrolysis extraction of nano-crystalline cellulose from coir fiber and its application in composite films was investigated by Azeredo and colleagues [10]. Jute, one of the common agro-fiber, was also used as raw material for the preparation of microcrystalline cellulose [11]. Turkey is one of the leading textile producers, therefore vegetable fiber wastes having high cellulose content release in the different steps of textile production processes. Recycling of these wastes and reusing them as a raw material offer economic and social benefits to the country. Hence, in our previous studies extraction and characterization of cellulose from waste of various vegetable fibers were also considered [12-14].

In this study, it is aimed to provide sustainability with recycling of cellulose from waste jute fibers, considering the amount of waste jute weft yarns released in the production process of machine carpets. For this purpose, pre-cleaning of waste fibers was carried out at first, and then extraction of cellulose was accomplished via organic acid extraction, and finally characterization of recycled cellulose was performed. The structures and properties of recycled and control cellulose were compared and discussed.

\section{MATERIALS AND METHOD}

\section{Materials}

In this study waste jute yarns, which is released during machine carpet production, were used to extract cellulose. Commercial cellulose was purchased from Sigma-Aldrich for the comparison of analyse results. Other chemical agents such as formic acid (98-100\%), hydrogen peroxide (35\%), ethanol, benzene, ethylenediaminetetraacetic acid (EDTA), hydrochloric acid (37\%), sulfuric acid, acetone and copper (II) ethylenediamine solution (CUEN) were also supplied from Sigma-Aldrich.

\section{Methods}

\section{Determination of chemical composition}

Chemical composition of the waste fibers was determined to confirm the high cellulose content of jute considering the China Textile Industry Standard [15]. At first, waste fibers were dried in vacuum oven for 8 hours at $105^{\circ} \mathrm{C}$ in order to achieve dry weight of samples, and then pectin composition of samples was determined with $0.5 \%$ EDTA solution. Hydrochloric acid $(0.5 \mathrm{M})$ was used to obtain the hemicellulose content and sulfuric acid $(72 \% \mathrm{v} / \mathrm{v})$ was used to determine both the cellulose and klason lignin content of the samples.

\section{Extraction of cellulose}

In our study; at first pre-cleaning of waste fibers with hot distilled water were carried out to remove water soluble contents. Waste fibers are cut into 1-2 cm small pieces and washed for 3 hours at boiling temperature. Afterwards, fibers were dried in an oven for 8 hours at $105^{\circ} \mathrm{C}$ for further process. For the removal of water insoluble content of waste fibers such as wax and lipophilic materials, another treatment was carried out. Washed and dried fiber bundles were placed in a soxhlet apparatus and treated with a mixture of $2: 1$ benzene/ethanol at $80^{\circ} \mathrm{C}$ for 6 hours. The remaining solution was stored to reuse. After soxhlet-extraction, fiber material was washed to remove possible residues with ethanol and acetone, respectively. For the final step of cleaning, fibers were rinsed with distilled water and dried at room temperature [12].

Extraction of cellulose was performed by using organic acid pulping and hydrogen peroxide bleaching [11,13-14]. Organic acid pulping can be effectively used to obtain cellulose from soft wood materials [16]. In organic acid pulping formic acid and peroxyformic acid were used for delignification, respectively. Firstly, formic acid in $90 \%$ concentration was used to remove the non-cellulosic materials of waste fibers. Peroxoacids are synthesized using a carboxylic acid and hydrogen peroxide according to the following reaction

$$
\mathrm{RCOOH}+\mathrm{H}_{2} \mathrm{O}_{2} \rightleftarrows \mathrm{RCOOH}+\mathrm{H}_{2} \mathrm{O}
$$

If a strong mineral acid is not used as a catalyst for the proton donation, this reaction is reversible and slow. However, strong mineral acids such as sulfuric acid cause deterioration of the pulp and decrease dramatically the degree of polymerization of cellulose [17]. Considering these disadvantages of sulfuric acid, formic acid and hydrogen peroxide were used to synthesize the peroxyacid in this study. Following the formic acid treatment, peroxyformic acid treatment with hydrogen peroxide $35 \%$ concentration was carried out to improve delignification. Samples are washed with peroxyformic acid for 150 minutes and then dried. Finally, bleaching of obtained material was performed with hydrogen peroxide for $75 \mathrm{~min}-$ utes at $60^{\circ} \mathrm{C}$. Lignin-hemicellulose bonds and hemicellulose itself were also hydrolyzed with this method [18]. During extraction of cellulose, the weight loss of the starting material was also noted down after every process step to calculate yield ratio. Starting material (waste jute fibers), pulping process and the extracted material (recycled cellulose) can be seen in figure 1 .

\section{Characterization of recycled cellulose}

Experimental analyses were carried out to characterize the recycled cellulose and to make a comparison with control cellulose. The degree of polymerization (DP) was calculated by viscosity method. Viscosity measurement was carried out with ViscoSytem AVS470 at $20^{\circ} \mathrm{C}$ with iron (III) sodium tartrate complex (EWNN mod $\mathrm{NaCl}$ ) solution. Method is adapted from DIN 54270-3 standard. Structural analyses of recycled cellulose and reference cellulose were carried out by using Fourier Infrared Spectroscopy (FTIR) and X-Ray Diffraction (XRD) methods. FTIR measurements were performed by using Perkin Elmer Spectrum BX instrument, wavelength $400-4000 \mathrm{~cm}^{-1}$, $2 \mathrm{~cm}^{-1}$ resolution (\% absorbance) and XRD analyses 


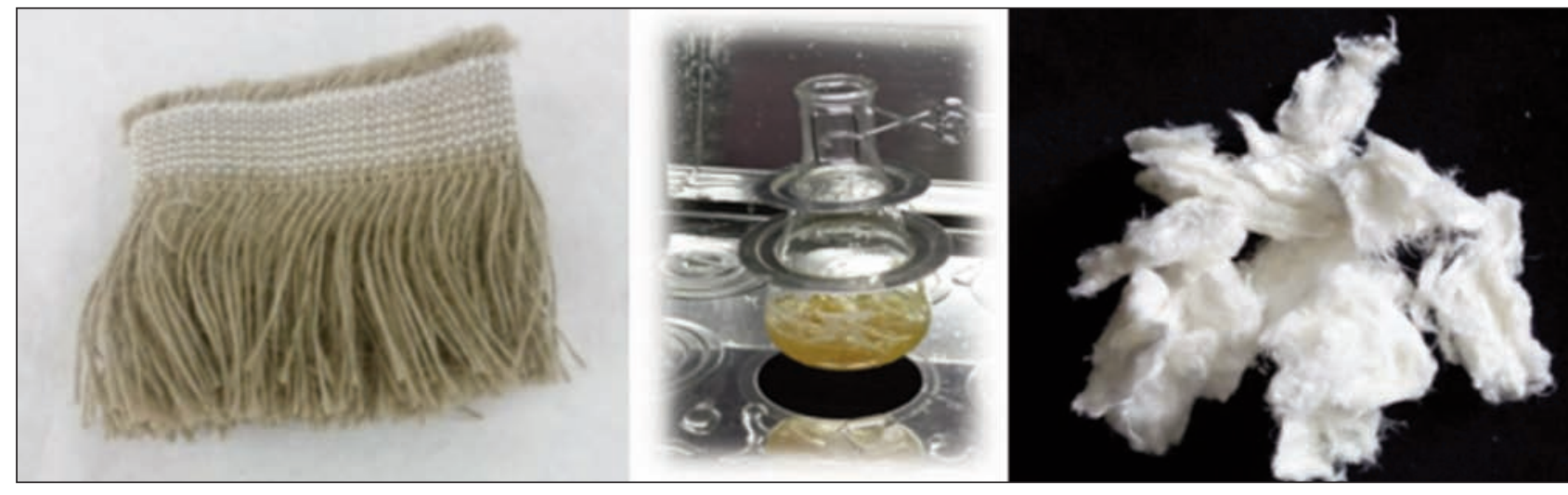

Fig. 1. Waste jute fibers, pulping process and recycled cellulose

by Rigaku D/MAX200 X-Ray diffractometer using CuKa radiation and operating at $40 \mathrm{kV}$ and $36 \mathrm{~mA}$. The diffraction intensities of the reference cellulose and extracted cellulose were recorded between $3^{\circ}$ and $90^{\circ}(2 \theta)$. The crystallinity indexes of cellulose samples were calculated considering peak height method [19]. Thermal stability analysis of samples were carried out using Perkin Elmer Simultaneous Thermal Analyzer (STA) 6000, in nitrogen medium and scanned between $25-600^{\circ} \mathrm{C}$ at a heating rate of $10^{\circ} \mathrm{C}$ per minute. Gravimetric method was used to determine the moisture content of cellulose samples. Solubility of the extracted cellulose was observed with optical microscope (Olympus BX43) using CUEN solution. Colour measurement of the various cellulosic samples was performed with Minolta 3600D CM spectrophotometer (D65 illuminant specular included, $10^{\circ}$ observer angle) for comparison. The spectrophotometer, having a software, that could calculate $C I E L^{*} a^{*} b^{*} C^{*} h^{0}$. The software also gives data about color strength $(\mathrm{K} / \mathrm{S})$ values from the reflectance values at the appropriate $\lambda_{\max }$ for each sample.

\section{RESULTS AND DISCUSSION}

\section{Chemical composition and pulp yield}

Chemical composition of the waste jute fibers and pulp yield are summarized in table 1 . The high cellulose content of waste fibers with $63.60 \%$ enhances the variety of utilization and sustainability. Pulp yield also shows that organic acid extraction method is effective for the extraction of cellulose from waste fibers.

Degree of polymerization and moisture contents Polymerization degree and moisture content of recycled ( $r$-cell) and control cellulose (a-cell) can be seen in table 2. DP of recycled cellulose is higher than reference cellulose; this is most probably due to the extraction method applied to waste fibers. Besides, DP of natural fibers is most variable as nature of cellulose formation. Moisture content of both sample are high and close to the moisture content of commercial cellulosic fibers [20]. Moisture content of recycled cel-

\begin{tabular}{|c|c|}
\hline \multicolumn{1}{|c|}{ Table 1 } \\
\hline Constituent & Content \% \\
\hline Cellulose & 63.60 \\
\hline Hemicellulose & 20.10 \\
\hline Lignin & 13.80 \\
\hline Pectin & 2.60 \\
\hline Pulp Yield & $43.65 \pm 0.25$ \\
\hline
\end{tabular}

Table 2

\begin{tabular}{|c|c|c|}
\hline Sample & DP & Moisture content (\%) \\
\hline r-cell & $1106.0 \pm 117.5$ & $7,78 \pm 0.14$ \\
\hline a-cell & $872.0 \pm 87.0$ & $8.44 \pm 0.15$ \\
\hline
\end{tabular}

Iulose is less than control cellulose as a result of different DP and crystal structure of samples.

\section{Structural analysis}

FTIR results which were performed to analyze and compare the functional groups and bond energies of recycled and control cellulose, are given in figure 2.

As it can be seen in FTIR spectra of the recycled and control cellulose (fig. 2), similar peaks between absorption bands $700-1800 \mathrm{~cm}^{-1}$ and $2400-3600$ $\mathrm{cm}^{-1}$ were observed. The absorption bands at around 3300 and $1028 \mathrm{~cm}^{-1}$ in FTIR spectra of the cellulose samples are assigned to $\mathrm{O}-\mathrm{H}$ stretching vibrations and cyclic alcohol groups, respectively. The peak at around $2900 \mathrm{~cm}^{-1}$ absorption band, which is assigned to $\mathrm{CH}_{2}$ and $\mathrm{CH}_{3}$ vibrations, is similar for both samples. The band at $1228 \mathrm{~cm}^{-1}$ noticed in FTIR spectra of the samples is attributed to axial asymmetric strain of $=\mathrm{C}-\mathrm{O}-\mathrm{C}$ groups which are observed in ether, ester, and phenol groups [21].

XRD patterns of recycled and control cellulose are shown in figure 3 . The diffraction peaks at $2 \theta=$ $22-23^{\circ}(002)$ and $2 \theta=18-19^{\circ}(110)$ indicate the typical diffractions of cellulose [21]. Crystallinity indexes of recycled and control cellulose samples were calculated as $78.87 \%$ and $74.41 \%$, respectively. XRD patterns of the samples show the same intensity peaks at the same diffraction angles.

Thermo gravimetric analysis (TGA) was conducted to investigate the effect of extraction on thermal behavior 


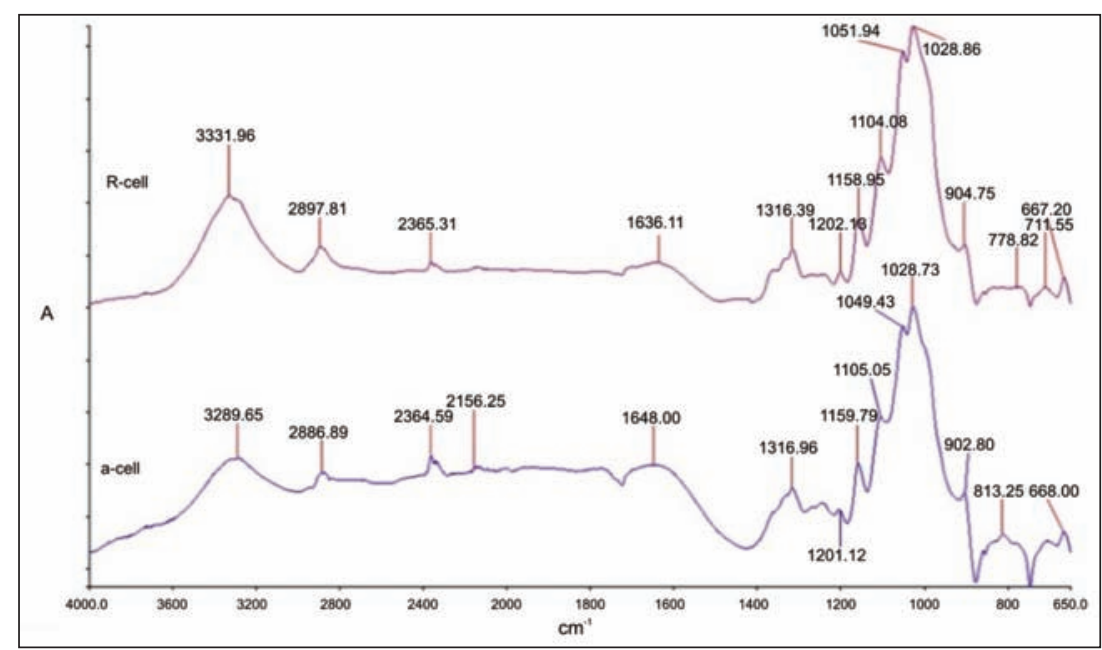

Fig. 2. FTIR spectra of the cellulose samples

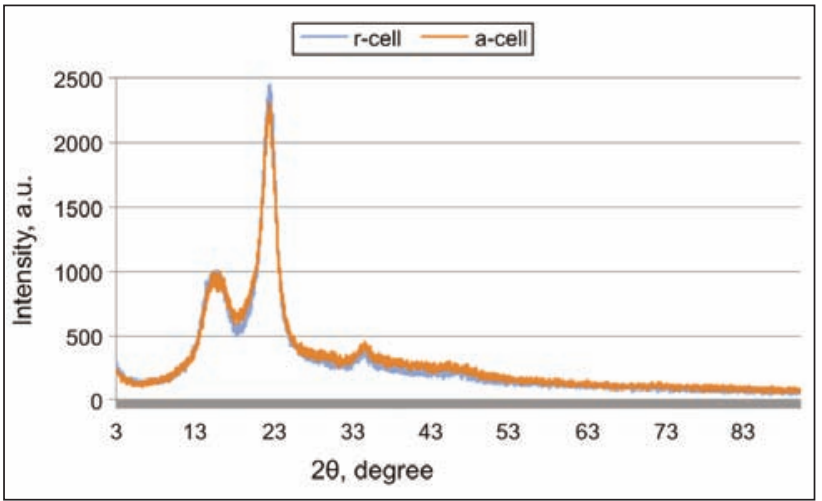

Fig. 3. XRD patterns of the cellulose samples

of recycled cellulose. TGA curves of the cellulose samples are presented in figure 4 . The initial weight loss, which represents the evaporation of water, was observed between 50 and $100^{\circ} \mathrm{C}$. Weight losses in samples between these temperatures are compatible with moisture absorption values of samples indicated in table 2. The second weight loss was recorded between $260^{\circ} \mathrm{C}$ and $320^{\circ} \mathrm{C}$ which is related to the decomposition of hemicellulose and the glycosidic linkages of cellulose. The third weight loss was detected between $320^{\circ} \mathrm{C}$ and $390^{\circ} \mathrm{C}$ corresponds to the decomposition of cellulose [22]. After that, the weight loss was pursued until $600^{\circ} \mathrm{C}$ with a loss rate of about $92 \%$. Initial, maximum and the final degradation

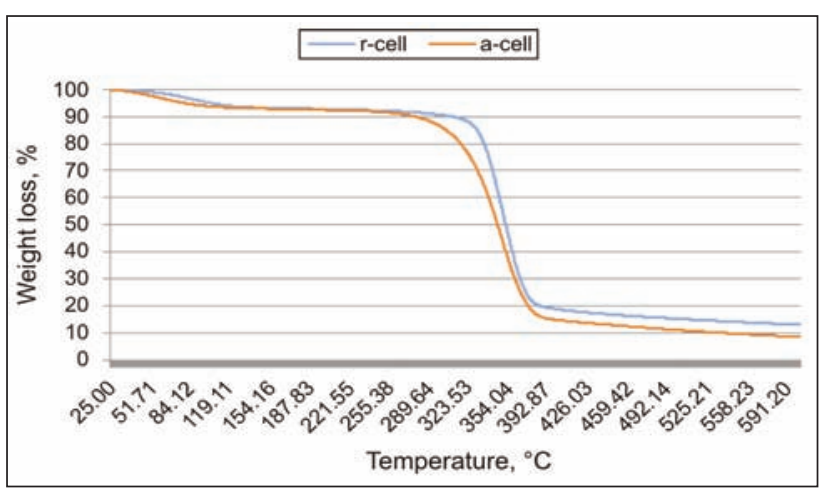

Fig. 4. TGA curves of the cellulose samples temperature of recycle cellulose is a little bit higher than control cellulose. This can be due to higher DP and crystallinity of recycled cellulose.

\section{Microscopic observations and color measurement}

Solubility of recycled cellulose was also observed with an optical microscope by using CUEN solution. CUEN is a well-known chemical which is used to solve cellulose in viscosity measurements.

Dissolution behavior of the recycled cellulose under microscope can be seen in figure 5 . As it can be seen from digital images of recycled cellulose, it began to fragmentize with the addition of CUEN and then completely dissolved by the time (approximately within one minute).

The colorimetric values of the waste jute fiber, viscose and recycled cellulose are summarized in table 3. Since, the control cellulose is in powder form, color of it was not measured and considered in this test. Waste jute has the highest yellowness $\left(b^{*}\right)$ and lowest lightness $(\mathrm{L})$ value as it is expected. Similar yellowness $\left(b^{*}\right)$ and lightness $(L)$ values were obtained for the recycled cellulose and viscose fiber. K/S and $\mathrm{R} \%$ which indicate the color strength and reflectance values of samples are also given in table 3 .

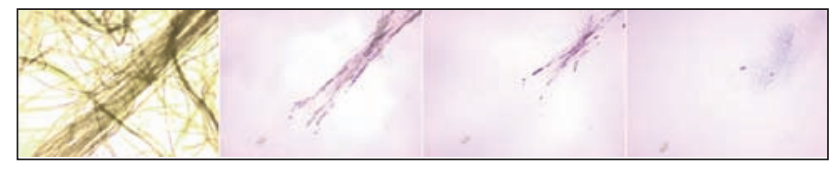

Fig. 5. Solubility of recycled cellulose under microscope with CUEN solution (50x)

Table 3

\begin{tabular}{|l|c|c|c|c|}
\hline \multicolumn{1}{|c|}{ Sample } & $\mathbf{L}$ & $\mathbf{b}^{*}$ & $\begin{array}{c}\text { \%R }(\mathbf{m i n}) \\
(\mathbf{4 0 0} \mathbf{n m})\end{array}$ & $\begin{array}{c}\text { K/S (max) } \\
(\mathbf{4 0 0} \mathbf{n m})\end{array}$ \\
\hline r-cell & 91.542 & 4.736 & 67.75 & 0.0768 \\
\hline waste jute & 61.393 & 18.130 & 12.12 & 3.186 \\
\hline viscose fiber & 93.934 & 2.222 & 77.73 & 0.0319 \\
\hline
\end{tabular}

\section{CONCLUSION}

In this study, extraction and characterization of cellulose was considered from waste jute fibers which release in machine carpet production. Thus recycling of a valuable polymer was achieved. Organic acid extraction method was effective for the regaining of cellulose from waste fibers with $43.65 \%$ yield performance. Microscopic and experimental analyses confirmed that non-cellulosic part of waste fibers were removed successfully and recycled cellulose has similar structure with control cellulose. Our results suggest that, waste vegetable fibers can be used as a potential source for cellulose. Recycled cellulose can be used in the production of paper, composites 
and regenerated cellulose fibers. Moreover, micro and nano crystalline cellulose may be produced from recycled cellulose and they can be used as a raw material of packaging industry. Consequently, the results of this project are important for both environmental and economic perspective since cellulose is a valuable biopolymer for various industries. Further study is now carried out by our research group to spin functional regenerated cellulose fiber using the recycled cellulose obtained in this study.

\section{Acknowledgement}

The authors gratefully acknowledge the funding by Scientific and Technological Research Council of Turkey (TÜBITAK) under grant 115M736. We also thank machine carpet companies Atlantik, Serko and Mutaş for their supports and technical assistances.

\section{BIBLIOGRAPHY}

[1] Kozłowski, R.M. Handbook of natural fibres, Elsevier, 2012.

[2] Muthu, S.S. Textiles and clothing sustainability: Recycled and upcycled textiles and fashion, Springer Singapore, 2017.

[3] Klemm, D., Heublein, B., Fink, H-P., Bohn, A. Cellulose: Fascinating biopolymer and sustainable raw material, In: Angew and the Chemie International Edition, 2005, Vol. 44, no. 22, pp. 3358-3393.

[4] Islam, M.T., Alam, M.M., Patrucco, A., Montarsolo, A., Zoccola, M. Preparation of nanocellulose: A review, In: AATC Journal of research, 2014, Vol. 1, no. 5, pp. 17-23.

[5] Reddy, K.O., C. Maheswari U., E. Shukla M.M., Varada Rajulu, A. Extraction and characterization of cellulose from pretreated ficus (Peepal Tree) leaf fibers, In: Journal of Natural Fibers, 2016, Vol. 13, no. 1, pp. 54-64,

[6] Johar, N., Ahmad, I., Dufresne, A. Extraction, preparation and characterization of cellulose fibres and nanocrystals from rice husk, In: Industrial Crops and Products, 2012, vol. 37, no. 1, pp. 93-99.

[7] Elanthikkal, S., Gopalakrishnapanicker, U., Varghese, S., Guthrie, J. Cellulose microfibres produced from banana plant wastes: Isolation and characterization, In: Carbohydrate Polymers, 2010, vol. 80, no. 5, pp. 852-859.

[8] Kopania, E., Wietecha, J., Ciechańska, D..Studies on Isolation of Cellulose Fibres from Waste Plant Biomass, In: Fibres\& Textiles in Eastern Europe, 2012, vol. 20, no 96, pp. 167-172.

[9] Moran, J.I., Alvarez, V.A., Cyras, V.P., Vazquez, A. Extraction of cellulose and preparation of nanocellulose from sisal fibers, In: Cellulose, 2008, vol. 15, no. 1, pp. 149-159.

[10] Azeredo, H.M.C., Imam, S.H., Figueire, M.C.B., Nascimento, D.M., and Morsyleide, F.R. Handbook of polymer nanocomposites. Processing, performance and application - Volume C: Polymer nanocomposites of cellulose nanoparticles, Springer, 2014.

[11] Jahan, S.M., Saeed, A., He, Z., Ni Y. Jute as raw material for the preparation of microcrystalline cellulose, In: Cellulose, 2010, vol. 18, no. 2, pp. 451-459.

[12] Erdoğan, U.H., Duran, H. Cellulose from waste jute fibers: Extraction and characterization, In: IFATCC XXIV International Congress Book of Abstracts, Czech Republic, Pardubice, 2016, pp. 161-164

[13] Erdogan, U.H., Selli, F., Duran, H. Banana plant waste as raw material for cellulose extraction. In: Fiber and Textiles, 2017a, vol. 24, no. 3, pp. 48-52.

[14] Erdogan, U.H., Selli, F., Duran, H. Using sisal fiber wastes to isolate cellulose, In: 8th TEXTEH International Conference. Bucharest, Romania, 2017b, pp. 19-20.

[15] Zhang, J., Zhang, H., Zhang, J. Evaluation of liquid ammonia treatment on surface characteristics of hemp fiber, In: Cellulose, 2013, Vol. 21, no. 1, pp. 569-579.

[16] Jahan, M.S., Lee, Z.Z., Jin, Y., Organic acid pulping of rice straw. I: Cooking, In: Turkish Journal of Agriculture and Forestry, 2006, vol. 30, no. 3, pp. 231-239

[17] Kham, L., Bigot, Y., Delmas, M., Avigno, G. Delignification of wheat straw using a mixture of carboxylic acids and peroxoacids. In: Industrial Crops and Products, 2005, vol. 21, no. 1, pp. 9-15.

[18] Muurinen, E., Organosolv pulping: a review and distillation study related to peroxyacid pulping. In: Department of Process Engineering, University of Oulu, 2000.

[19] Park, S., Baker, J.O., Himmel, M.E., Parilla, P.A., and Johnson, D.K. Cellulose crystallinity index: measurement techniques and their impact on interpreting cellulase performance, In: Technology for Biofuels 2010, vol. 3, no. 1, pp. $1-10$.

[20] ASTM D 1909-04, Standard Table of Commercial Moisture Regains for Textile Fibers, 2004

[21] Erdoğan, U.H., Seki, Y., Aydogdu, G., Kutlu, B., Aksit, A. Effect of different surface treatments on the properties of jut, In: Journal of Natural Fibers, 2016, vol. 13, no. 2, pp. 158-171.

[22] Kılınç, A.Ç., Köktaş, S., Seki, Y., Atagür, M., Dalmış, R., Erdoğan, U.H., Göktaş, A.A., Seydibeyoğlu, M.Ö. Extraction and investigation of lightweight and porous natural fiber from Conium maculatum as a potential reinforcement for composite materials in transportation, In: Composites Part B, 2018, vol. 140, pp. 1-8c.

\section{Authors:}

\section{UMIT HALIS ERDOGAN, HICRAN DURAN, FIGEN SELLI}

Dokuz Eylul University, Department of Textile Engineering, 35390,Tınaztepe Campus, Buca, Izmir, Turkey e-mail: umit.erdogan@deu.edu.tr, duran.hicran@gmail.com, figenselli@gmail.com

\section{Corresponding author:}

UMIT HALIS ERDOGAN

e-mail: umit.erdogan@deu.edu.tr 